Conservation and Society 7(4): 249-267, 2009

$\underline{\text { Article }}$

\title{
Conservation-induced Displacement: A Comparative Study of Two Indian Protected Areas
}

\author{
Asmita Kabra \\ School of Human Ecology, Ambedkar University, Delhi, India \\ E-mail: asmita.kabra@gmail.com
}

\begin{abstract}
Attempts at 'preservation via displacement' are an extreme manifestation of the 'fortress' or an exclusionary conservation paradigm, support for which has increased lately due to escalating conservation threats. While the policies and processes emanating from this paradigm have produced positive conservation outcomes for some Protected Areas, livelihood outcomes for the displaced people have seldom been as positive. This article examines whether the impoverishment risks arising from conservation-induced displacement tend to vary with the degree of marginalisation of the displaced community. In this light, this article examines in detail the impact on livelihood of conservation-induced displacement in two Protected Areas (PAs) of India. The article posits that understanding the dynamic livelihood context of displaced communities, especially the ecological base of their livelihoods, is critical to any assessment of their pre- and post-displacement livelihood strategies and livelihood outcomes (such as income, poverty, food security and health). A variety of livelihood parameters, including compensation received, consumption flows, agricultural production, monetary income, food security, headcount ratio of poverty and overall poverty indices have been studied, to understand the extent to which key livelihood risks arising out of displacement are addressed by the rehabilitation package and process in the two PAs. The Sahariya is a forest-dependent Adivasi community living in and around the Kuno Wildlife Sanctuary in the semi-arid tropical region of Madhya Pradesh. The Sahariya Adivasis of the Kuno Sanctuary were a socially, politically and economically marginalised community, whose lives and livelihoods were intricately linked to their ecological base. We found that inadequate attention was paid to this factor while designing and implementing a suitable rehabilitation package for the 1650 Sahariya households displaced from this PA. As a result, their material condition deteriorated after displacement, due to loss of livelihood diversification opportunities and alienation from their natural resource base. Displacement thus resulted in rapid proletarianisation and pauperisation of these households, and their 'integration' into the national 'mainstream' occurred at highly disadvantageous terms. The 430 odd households displaced from the Bhadra Wildlife Sanctuary in the Western Ghats (a biodiversity hotspot in the Southern Indian state of Karnataka) consisted of relatively less marginalised social groups like the Gowdas and the Shettys, both of whom occupy a prominent place in the local politics and economy of this state. The share of agriculture in the pre-displacement livelihood of these households was relatively higher, and dependence on forest-based livelihoods was relatively lower than in the case of the Kuno Wildlife Sanctuary. I argue that this was an important factor that enabled these households to negotiate a better post-displacement deal for themselves. Consequently, the relocation package and process was far more effective in mitigating the potential impoverishment risks of these households. It appears, then, that the livelihood outcomes of conservation-induced displacement are generally biased against the poor. Further, the more marginalised a displaced community (or household) is, the less likely it is to obtain benign or positive livelihood outcomes after displacement. This has important implications for poverty and social justice, especially for Adivasi communities, which constitute a large proportion of those threatened with conservation-induced displacement, in India, in the coming years.
\end{abstract}

Keywords: conservation, displacement, livelihoods, Adivasi

DOI: $10.4103 / 0972-4923.65172$

Copyright: (C) Asmita Kabra 2009. This is an open access article distributed under the terms of the Creative Commons Attribution License, which permits unrestricted use and distribution of the article, provided the original work is cited. 


\section{INTRODUCTION}

Escalating conservation threats have in recent years given greater popular currency to the idea of creating 'inviolate' or 'people-free' zones, where natural processes can play out without 'human disturbances'. This idea of 'preservation via displacement' is the most extreme version of the dominant conservation paradigm of 'fortress' or exclusionary conservation. In this article, I shall argue that even though the policies and processes flowing from this paradigm are likely to produce positive conservation outcomes for some Protected Areas, historically the livelihood outcomes for the displaced people have not been as positive. A range of factorshistorical, political and socioeconomic - usually prevent local communities living inside Protected Areas from exercising their rights effectively to resist forced displacement, or from accessing proper compensation and rehabilitation benefits after relocation. In India and elsewhere, examples of successful resettlement and rehabilitation of households affected by conservation-induced displacement are rare, and unfulfilled promises and reduced livelihood security after relocation continue to be the norm (PRIA 1993; Rossi 2000; Chatty \& Colchester 2002; Geisler 2003; Schmidt-Soltau 2005).

This article takes a critical look at two recent displacement experiences in India - one fairly successful in livelihood restoration, and the other unsuccessful by most standards. Using the experience of these two Protected Areas - the Kuno Wildlife Sanctuary in the central Indian state of Madhya Pradesh and the Bhadra Wildlife Sanctuary in Karnataka in south India, I examine how the impoverishment risks and the destruction of livelihoods generally associated with displacement tend to vary with the degree of marginalisation of the displaced community. While focusing on the livelihood impact of conservation-induced displacement in these two PAs, I implicitly assume (based on available, albeit contested, evidence) that the biodiversity conservation impacts of displacing the local people are largely positive in both cases.

I use a variety of livelihood parameters, including compensation received, consumption flows, agricultural production, monetary income, food security, headcount ratio (HCR) of poverty and overall poverty indices, to assess the impact of displacement on people's livelihoods. These parameters comprehensively illustrate the extent to which livelihood risks arising out of displacement have been addressed by the rehabilitation package and process (not very successfully) in Kuno and (fairly successfully) in Bhadra, highlighting some key points about the viability of displacement as a conservation tool in countries like India. On the basis of my findings in these two PAs, I argue that understanding the dynamic livelihood context of displaced communities, especially the ecological base of their livelihoods, is critical to any assessment of the livelihood outcomes of displacement (in terms of impact on variables like income, poverty, food security and health). Moreover, local power dynamics and the position of the displaced community in local politics (and the corresponding social and political networks they have access to) critically determine their ability to 'play the system' to their advantage before and during the relocation process. This article demonstrates that a major limitation of the 'preservation via dislocation' strategy is its inherently regressive nature-among the people displaced from PAs, those who are politically marginalised tend to become more so, and are unable to obtain positive livelihood outcomes, while the more empowered and strong tend to corner all the advantages. This is especially true, for a variety of reasons, of Adivasi $^{1}$ communities facing conservation-induced displacement, and therefore more inclusive ways need to be found for practicing socially just biodiversity conservation in areas inhabited by Adivasis.

\section{WILDLIFE CONSERVATION IN INDIA}

Since the 1980s, pressure has been increasing on the government to conserve effectively the limited and dwindling natural wealth of the country. This has translated into tighter controls over resource use in the existing PAs, and an increase in the total area under the PA network. Coverage of land under such areas in India has risen from $0.5-5 \%$ of the landmass between 1969 and 2001 (Rangarajan 2001). The 'core areas', or the most highly conserved parts of PAs (where all rights of the local people to environmental resources are supposed to be 'extinguished') cover about $1 \%$ of the country's landmass (Kothari et al. 1989). Provisional estimates put the number of people living in and around PAs in India at around 4.5 million (Kothari et al. 1996), while the Planning Commission, in its Mid Term Review of the Ninth Plan, puts the number of people in India dependent on forests for sustenance at 100 million. The core and buffer zones of Tiger Reserves (formed under the government's flagship 'Project Tiger') alone contain nearly 1,500 villages (with around 65,000 families or 325,000 people), according to the 2005 Report of the Tiger Task Force, commissioned by the Government of India.

Notwithstanding the magnitude of people's dependence on PAs in India and the growing intensity of humanwildlife conflicts across the country, conservation research in India has not engaged adequately with the complexity of this issue (Rangarajan \& Shahabuddin 2006). A notable exception is the Tiger Task Force Report of 2005, which highlights that the wildlife-rich areas of India also happen to be, economically, among the poorest, and populated by the most marginalised Adivasi communities. This strong overlap between conservation and livelihood issues in India, and the resultant human-wildlife conflicts, underlie some of the most acrimonious debates on conservation issues in India.

\section{'FORTRESS' CONSERVATION AND DISPLACEMENT}

The steady rise in the number and geographical coverage of PAs in India has been accompanied by a rise in the number of conservation refugees-people who have been displaced as a consequence of conservation programmes. The nature of 
human impacts on PAs is the subject of much debate between those who advocate continued use of forest resources by local communities and those who argue for creation of inviolate zones'. The case for people's relocation from PAs (in India and elsewhere) has been built explicitly or implicitly on the hypothesis that human use of their resources causes their degradation over time (Grove 1987; McCracken 1987; Tiani \& Diaw 2006). This hypothesis postulates that people and wildlife cannot coexist, therefore, if natural areas are to be safeguarded, people will have to be removed (displaced forcibly or relocated voluntarily) from these. For instance, it is estimated that longterm conservation of the tiger in India requires 'increasing the area that supports demographically viable tiger populations to at least one-third of the estimated potential tiger habitats in India (about 100,000 sq. km )' (Karanth \& Gopal 2005).

However, in most cases of conservation-induced displacement that have been documented by researchers, it was found that the decision to displace people was high on rhetoric and low on facts. There are few examples anywhere in the world where site-specific studies were carried out a priori for quantifying the threat to a PA from the local population, alternative solutions were discussed and discarded, and conclusively established that human populations were the single most important threat and human displacement the most viable solution (Rangarajan \& Shahabuddin 2006).

After decades of following the exclusionist or 'fortress' approach to conservation, it is increasingly recognised that this is a serious lapse. For instance, the International Union for the Conservation of Nature (IUCN) challenged the 'fortress' model as early as 1980, in its World Conservation Strategy, and argued in favour of Integrated Conservation and Development Programmes, with active participation of local communities in conservation. However, dissatisfaction with the actual results obtained from such programmes across the world have fed back into strengthening the appeal of the exclusionary 'fortress' paradigm in conservation practice.

Despite the large number of already displaced people worldwide, by 'fortress' conservation strategies, or people facing displacement risks in the near future, displacement from PAs is generally a highly under-researched subject in India and South Asia. There are few rigorous studies on the phenomenon from the sociological, anthropological, historical, political, economic or ecological perspectives, and fewer still that look at inter-disciplinary linkages. A review of the existing literature on conservation-induced displacement has found that there are only 17 in-depth studies of resettlement of indigenous people from PAs worldwide. Moreover, not a single such study exists for India, while only one such study has been conducted (for Nepal) in all of South Asia (Brockington \& Igoe 2006).

In recent years, however, this issue has started coming to the forefront of academic and policy discussions in India. A preliminary attempt at quantifying conservation-induced displacement has been made in 2005 , by the Government of India's Tiger Task Force, which estimates that since the inception of Project Tiger in the 1970s, a total of 80 villages and 2,904 families (and 46,341 livestock) have been relocated from different tiger reserves. The report also estimates that around 1,590 families have been relocated during the same period from non-Project Tiger PAs. This article provides one of the first attempts in India to compare and contrast conservation-induced displacement experiences from two areas. It is based on detailed, field-based studies in these PAs, which take into account both ecological and livelihood aspects, with a view to deriving key policy lessons on the viability of the 'preservation via dislocation' strategy for the conservation of large carnivores.

\section{THE KUNO EXPERIENCE}

\section{Methodology}

The objective of our research in the Kuno Wildlife Sanctuary was to assess the effect of conservation-induced displacement on the livelihoods of the displaced people. The outcome variables included the household's aggregate income, food security, asset-holding pattern, share of wages in income, agricultural output and productivity, and distance traveled for collection of common pool resources, among others. The main methodological challenge was the lack of a suitable control group with which the outcome variables of the displaced households could be compared. Thus, the control group had to be created in an observational setting using a quasi-experimental research design. Care was taken to choose a control group (that is, non-displaced households) that were as similar as possible to the treatment group (that is, displaced households), in all experimentally relevant aspects. This included key parameters of livelihood, such as, access to forest resources, availability of common pool resources, socioeconomic condition, social organisation, remoteness from the 'mainstream' economy, and availability of infrastructure.

Selection of 'control' villages and households: The control group was selected from among the villages situated on or near the periphery of the Kuno wildlife sanctuary. After a careful study of various parameters, Bagcha village on the western boundary of the Kuno Sanctuary and Surde village on the eastern boundary were selected for our study. Both villages had a predominantly Sahariya population, and were located close to the Kuno sanctuary, at some distance from the nearest road and railway links. Penetration of government facilities was low in both villages, and access to forests and commons varies from good (Surde) to very high (Bagcha). Both villages were located close to good sources of water, and the quality of agricultural land here ranged from good to very good (on the basis of indicators like soil depth, moisture retention capacity, and soil type and quality). Both were villages with a history of settled agriculture for one or more generations. In both villages, individual households typically combined subsistence agriculture with a range of other activities like wage work, livestock rearing, hunting and collection of forest produce.

Selection of the 'treatment' villages and households: Another methodological challenge during this research was to identify an appropriate sample from among the displaced 
households, from which information could be collected about the impact of displacement on livelihood. The official number of households displaced from the Kuno sanctuary was close to 1,650 , with a population of around 5,000 people. The treatment group selected for our study consisted of a universal sample of households in two displaced villages, named Paira and Jakhoda. The households surveyed in Paira and Jakhoda were found to be representative of the range of livelihood outcomes generated by displacement, in terms of ethnic composition, quality of land received after relocation, access to forest resources and availability of social and economic infrastructure. Coverage of an entire village for fielding the survey questionnaires was also important from the point of view of the respondents' participation, since random selection of a few households in any village would have led to suspicion and possible non-participation on the part of the selected respondents.

Table 1 provides a comparison of the control and treatment groups in terms of the key parameters affecting livelihoods. It is important to note that the data for the treatment villages pertains to their pre-displacement situation.

Data collection tools: Following the best practice principles of poverty and livelihood research (Ellis 2000), a combination of quantitative and qualitative methods were used to generate primary data for this study. This method has been successfully tested in many countries in the context of land restitution (Brockington \& Schmidt-Soltau 2004). Participatory Rural Appraisal-based methods, such as, informal group discussions, open-ended interviews and key informant interviews were used to collect qualitative information about livelihoods, changes in resource access, and livelihood-related activities, constraints, trends and problems at the level of the village or community. Additionally, a questionnaire-based survey was used to generate household level quantitative data on income and other parameters. For this, semi-structured interviews were conducted in all 165 displaced households in the 'treatment' (displaced) villages of Jakhoda and Paira. The same survey was also carried out in 121 households in the two 'control' (non-displaced) villages, Bagcha and Surde. Secondary data on livelihood, landholding, and other social and economic parameters were collected from various sources including libraries, census, cadastral surveys, other government records, published and unpublished and 'grey literature' prepared by academics and voluntary organisations.

\section{The area and the people}

The Kuno Wildlife Sanctuary is located in the Gird AgroEcological Sub-Region (AESR) in the central Indian state of Madhya Pradesh, which includes the districts of Bhind, Gwalior, Morena, Sheopur and Shivpuri. The Gird AESR accounts for $10 \%$ of the total area and $11 \%$ of the population of Madhya Pradesh. The Gird is classified as a moist semiarid region, with average rainfall of 800 to $1,000 \mathrm{~mm} / \mathrm{year}$, and is characterised by alluvial, loamy soils. An overview of the agricultural statistics of the Gird AESR reveals that the

Table 1

Comparison between control and treatment groups on key parameters

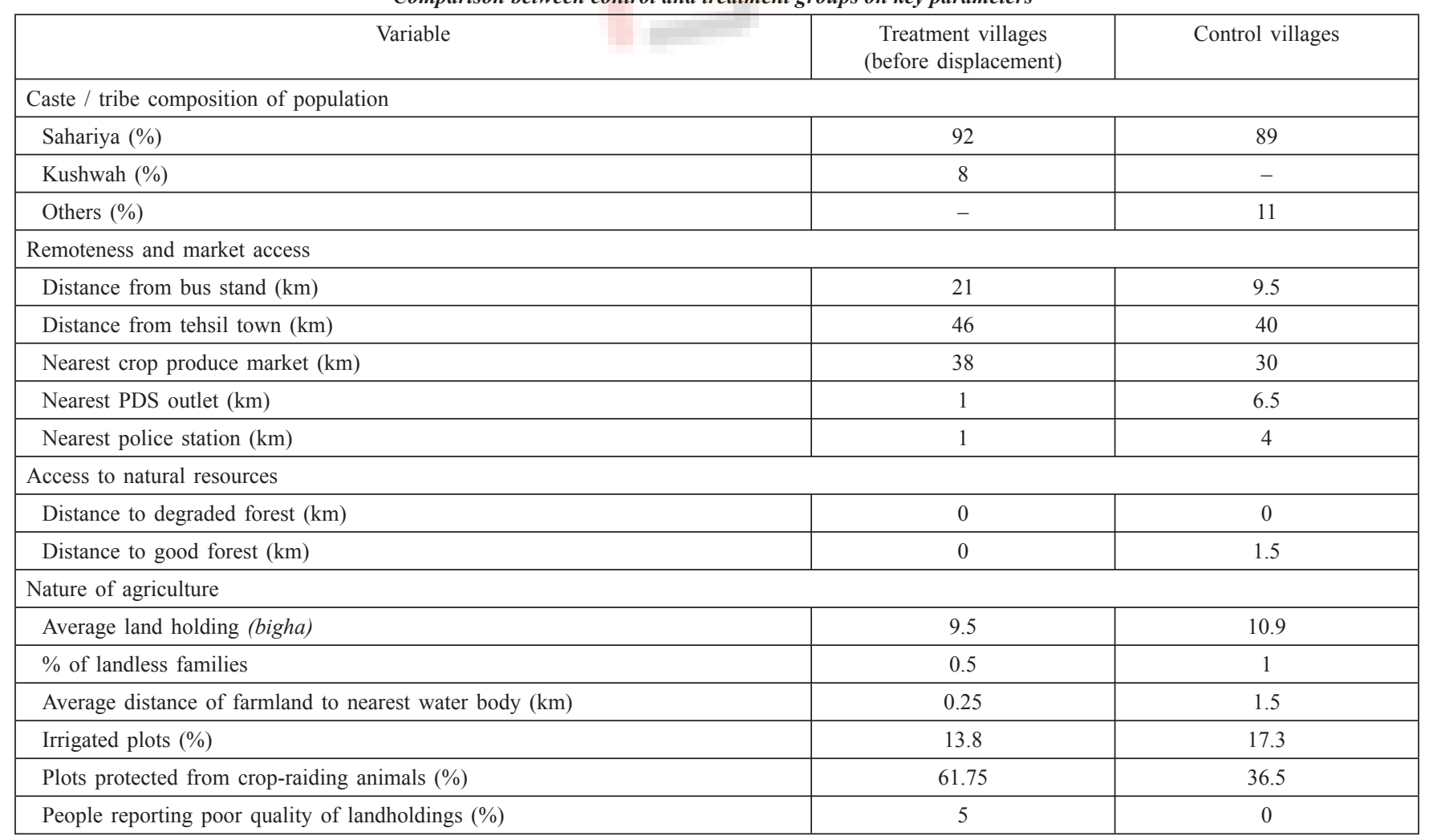


ratio of the net sown area to the total geographical area in this region is among the highest in Madhya Pradesh, and the area under wastelands and forests is proportionately lower. The irrigation ratio (gross irrigated area as a proportion of gross cropped area) in Gird is again among the highest in Madhya Pradesh, since a large section of the lowlands in this region falls in the command area of surface irrigation schemes like the Chambal Valley project. Average productivity of agriculture in Gird is the highest among all AESRs of Madhya Pradesh, and has posted a rate of growth of over 3\% between the 1980s and 1990 s, compared to a state average of $2.4 \%$ (Vijay Shankar 2005).

Adivasis form around $6 \%$ of the total population of Gird, and there are only two blocks in this AESR where tribals form over $25 \%$ of the population. In this sense, the Adivasi population (mainly the Sahariya) in the Gird region shows a classic pattern of 'enclavement', and occupies almost a minority status in the population. Sahariya villages are concentrated in the upland, in the forested and hilly tracts of the Gird AESR and are surrounded by large masses of non-Adivasi populations. The economic activities of the Adivasi households are significantly less market-oriented and profitable than the livelihood practices of the non-Adivasi people (Kabra 2008). The Sahariya Adivasi community of Gird thus constitutes an island of poverty, vulnerability, socioeconomic distress and political disempowerment, concentrated in the neglected, rain fed pockets of an otherwise agriculturally well-off AESR. As such, their situation reflects the uneven nature of agricultural development in the rest of Madhya Pradesh, and indeed, in India. Decades of neglect, official apathy and lack of adequate investments by the state in the development of such rain-fed, semi-arid areas has resulted in a very high concentration of poverty and vulnerability in India's drylands, and the situation of the Sahariya tribals of Gird AESR is no different from this overall scenario (Shah 2005).

\section{The Kuno wildlife sanctuary}

The Sheopur Forest Division was noted during the regime of the erstwhile Gwalior state for the variety of its wildlife. Apart from other wildlife, the tiger was found in abundance in the North Karahal, East and West Kuno, Imalia, Khadi and Piparwas Forest Blocks (Sinha 1996). Located between latitudes $25^{\circ} 30^{\prime} \mathrm{N}$ and $25^{\circ} 53^{\prime} \mathrm{N}$ and longitudes $77^{\circ} 07^{\prime} \mathrm{E}$ and $77^{\circ} 26^{\prime} \mathrm{E}$, the Kuno Wildlife Sanctuary (also referred to as the Kuno-Palpur or Palpur-Kuno Wildlife Sanctuary) covers a total area of 344.686 sq. km. The Sanctuary was notified vide Government of Madhya Pradesh Forest Department Notification No. 15/8/79/10/2 Bhopal, dated 16 January 1981. It is located $80 \mathrm{~km}$ north of the city of Shivpuri, $30 \mathrm{~km}$ off the highway connecting Shivpuri to the district headquarters at Sheopur.

The Sanctuary, located in the Vindhyas, falls in the semiarid zone and its terrain is typical of the Central Indian Highlands, interspersed with woodlands and meadows. The vegetation too is typical of dry deciduous forests dominated by Acacia catechu, Anogeissus pendula, Acacia leucophloea and Boswellia serrata. All the faunal representatives of the dry deciduous forests of Central India can be found in the Kuno Sanctuary. The deer family is represented by chital (Axis axis), sambar (Cervus unicolor) and barking deer (Muntiacus muntjak). Antelopes found in the Sanctuary include chinkara (Gazella gazella), nilgai (Tragocamelus bosalaphus), chowsingha (Tetracerus quardricornis) and blackbuck (Antelope cervicapra). Hanuman langur (Presbytis entellus) and rhesus macaque (Macaca mulatta) represent the primates. Wild pig (Sus scrofa) and sloth bear (Melursus ursinus) can also be found. Among carnivores, jungle cat (Felis chaus), wild dog (Cuon alpinus), leopard (Panthera pardus) and a small number of tigers (Panthera tigris) are also present. River Kuno, a tributary of the river Chambal (a major river of Central India), bisects the Sanctuary from south to north. The average rainfall in the area is $750 \mathrm{~mm}$ per year. The maximum temperature can rise up to $49^{\circ} \mathrm{C}$ while the minimum temperature recorded has been $2^{\circ} \mathrm{C}$.

In 1995, the Kuno Wildlife Sanctuary was selected by researchers from the Wildlife Institute of India as the best of three potential sites, for the reintroduction of a pride of the endangered Asiatic Lion from the Gir National Park in Gujarat, as part of the ambitious Asiatic Lion Reintroduction Project of the Government of India (Wildlife Institute of India 1995). The Madhya Pradesh Forest Department began implementing the Lion Reintroduction Project in 1998, with financial assistance from the Government of India. According to the recommendations of the Wildlife Institute of India, proper resettlement and rehabilitation of the people living inside the Kuno Sanctuary was an important precondition for the successful reintroduction of lions into the Sanctuary. This was considered vital for minimising the probability of conflicts (in the form of cattle depredation and attacks on human beings) between a large predatory carnivore like the lion and the local people.

\section{Relocation of villages from Kuno wildlife sanctuary}

Resettlement and rehabilitation of villages from the Kuno Sanctuary were carried out in accordance with the provisions of the Beneficiary Oriented Scheme for Tribal Development, a Centrally Sponsored Scheme of the Government of India's Ministry of Environment and Forests. The Madhya Pradesh Forest Department, specifically the Divisional Forest Officer responsible for managing the Kuno Wildlife Sanctuary, was entrusted with field level implementation of village resettlement and rehabilitation. A Relocation Plan was developed by the then incumbent Divisional Forest Officer, and village displacement and resettlement was carried out during 1998-2003 (Table 2) using this as the base document.

As part of the resettlement and rehabilitation package, every male above the age of 18 years was considered a separate family and was entitled to compensation worth INR 100,000, as detailed in Table 3. 
Table 2

Time line of village relocation under the Lion Reintroduction Project

\begin{tabular}{|l|c|}
\hline \multicolumn{1}{|c|}{ Description of activity } & Year \\
\hline Formulation of the relocation plan initiated by the Kuno Sanctuary management & 1995 \\
\hline Visit by the Cabinet sub-committee to assess whether villagers were willing to shift out voluntarily & 1996 \\
\hline $\begin{array}{l}\text { Pre-relocation activities like compilation of a list of beneficiaries, identification of land for resettlement, steps for } \\
\text { de-notification of identified land from forest to revenue }\end{array}$ & $1997-1998$ \\
\hline The first two villages, Khallai and Barrer shifted out & 1998 \\
\hline Villages located on the western bank of River Kuno shifted out & $1998-1999$ \\
\hline Most villages on the eastern bank of River Kuno shifted out gradually & $1999-2002$ \\
\hline Parond, the last village left inside the Sanctuary, shifted out & 2003 \\
\hline Asiatic Lion Reintroduction from Gir, Gujarat & Yet to occur \\
\hline Payment of compensation for land and other assets acquired & Ongoing in January 2009 \\
\hline
\end{tabular}

Table 3

The rehabilitation package under the Beneficiary Oriented Scheme for Tribal Development Scheme

\begin{tabular}{|l|c|}
\hline \multicolumn{1}{|c|}{ Heads } & $\begin{array}{c}\text { Specified norms } \\
\text { (INR per family) }\end{array}$ \\
\hline Land development (2 hectares per family) & 36,000 \\
\hline $\begin{array}{l}\text { House construction (on 5,000 sq. feet of } \\
\text { land per family) }\end{array}$ & 36,000 \\
\hline Community facilities & 9,000 \\
\hline Fuel and fodder plantation & 8,000 \\
\hline Pasture development & 8,000 \\
\hline Transport of household goods & 1,000 \\
\hline Cash incentive for shifting & 1,000 \\
\hline Miscellaneous expenses & 1,000 \\
\hline Total & $1,00,000$ \\
\hline
\end{tabular}

\section{Impact of displacement on livelihood}

Overall trends in income: The monetised value of average annual per capita consumption of displaced households was found to be around INR 4,200 (or INR 12 per person per day), compared to nearly INR 9,450 (INR 27 per day) in nondisplaced households. Thus, the average per capita income after displacement declined to less than $50 \%$ of the pre-displacement income. Pure monetary income of displaced households was also found to be significantly lower at around INR 2,500 per annum, compared to nearly INR 7,700 for non-displaced households. An important reason for this decline was the loss of access to forest resources after displacement, leading to loss of earnings through sale of non-timber forest produce (NTFP).

Sectoral break-up of income: The balance of income sources appears to have changed radically after displacement (Table 4), with higher dependence on relatively insecure sources like wage labour, as compared to traditional sources like agriculture and sale of NTFP. On an average, contribution of agriculture to the total income of households was found to be $15 \%$ in the nondisplaced Bagcha village, and $35 \%$ in Surde village. In contrast, agriculture accounted for only 4 and $8 \%$, respectively, of the total income of displaced households in Paira and Jakhoda villages. The move from well-drained, fertile, low-lying land inside the Kuno Sanctuary to unirrigated and rocky upland farm plots at the relocation site has introduced a much higher element of uncertainty and risk into the dryland agriculture of the displaced villages, making it a less viable livelihood option.

In the displaced households, income from local and migrant wage labour was found to contribute to around $37 \%$ of the total household income, while the corresponding share in non-displaced villages was much lower, at around $11 \%$. Thus, displacement appears to have compromised the livelihood self-sufficiency of the Sahariya, resulting in the creation of a reserve army of unemployed labour with vulnerable and insecure livelihoods.

It is instructive to disaggregate the sectoral contribution to average household income by different income brackets in the displaced and non-displaced villages, in order to understand the diversity of livelihood practices prior to displacement, as well as some common post-displacement trends. In the nondisplaced village of Bagcha, the richest households derived the largest share of their income from non-wood forest produce and 'other' activities, while the poorest households were more dependent on agriculture (Table 5a). In the non-displaced village of Surde, however, the trend was the reverse, with the richer households being primarily agriculturalists, while the poor depended more on NTFP (Table 5b). The key to this lies in the nature of the forest products available in the vicinity of the two non-displaced villages that we studied. Bagcha had easier access to high-value NTFP, for which collection time was lower relative to value received from sale (which was as high as INR 100 per kg for some products). For Surde village, the drudgery involved in NTFP collection was relatively high, and most products available in its vicinity sold for less than INR 5 per kg. Thus, the rich households in Bagcha concentrated on NTFP collection and sale, while only the poor households in Surde chose this livelihood option voluntarily. Moreover, in Surde, the richest households derived a higher share of their income from 'other sources', of which milk production from livestock was an important component. This indicated an integrated farming and livestock-rearing economy in Surde, typical of dryland areas in the semi-arid tropics. 
Table 4

Break-up of income by source in displaced and non-displaced villages

\begin{tabular}{|l|c|c|c|c|}
\hline \multirow{2}{*}{ Village } & \multicolumn{4}{|c|}{ Contribution of various sectors (\%) } \\
\cline { 2 - 5 } & Agriculture & Wages & NTFP & Others \\
\hline Bagcha & 15.2 & 8.7 & 65.7 & 10.5 \\
\hline Surde & 35.3 & 13.5 & 30.3 & 21.0 \\
\hline Jakhoda & 4.2 & 34.9 & 30.5 & 30.4 \\
\hline Paira & 7.7 & 38.7 & 35.0 & 18.6 \\
\hline
\end{tabular}

Table 5a

Break-up of sectoral shares by household income categories: Bagcha village

\begin{tabular}{|c|c|c|c|c|c|c|c|}
\hline \multirow{2}{*}{$\begin{array}{l}\text { Annual per capita } \\
\text { income (INR) }\end{array}$} & \multirow{2}{*}{$\begin{array}{l}\text { No. of households } \\
\text { as a \% of total } \\
\text { households in village }\end{array}$} & \multirow{2}{*}{$\begin{array}{l}\text { Mean value of } \\
\text { annual PCY } \\
\text { (INR) }\end{array}$} & \multirow{2}{*}{$\begin{array}{l}\text { Mean value of daily } \\
\text { PCY (INR) }\end{array}$} & \multicolumn{4}{|c|}{ Income contribution from different sectors $(\%)$} \\
\hline & & & & Agriculture & Wages & NTFPP $^{a}$ & $\begin{array}{c}\text { Other } \\
\text { sectors }\end{array}$ \\
\hline Less than 500 & - & - & - & - & - & - & - \\
\hline $500-2,000$ & - & - & - & - & - & - & - \\
\hline $2000-5,000$ & 13 & 4,181 & 11 & 20 & 16 & 63 & 1 \\
\hline $5000-10,000$ & 34 & 7,547 & 21 & 16 & 10 & 64 & 9 \\
\hline $10,000-15,000$ & 21 & 12,185 & 33 & 12 & 11 & 68 & 9 \\
\hline $15,000-50,000$ & 30 & 25,248 & 69 & 13 & 8 & 67 & 11 \\
\hline
\end{tabular}

${ }^{\mathrm{a} C}$ Consists of income from sale of NTFP, imputed value of NTFP collected for self-use, and imputed value of fuelwood collected from forests and commons, ${ }^{\mathrm{b} C o n s i s t s ~ o f ~}$ imputed or realised value of milk production from livestock, along with income from sale of non-farm goods or poultry

Table 5b

Break-up of sectoral shares by household income categories: Surde village

\begin{tabular}{|c|c|c|c|c|c|c|c|}
\hline \multirow{2}{*}{$\begin{array}{l}\text { Annual per capita } \\
\text { income (INR) }\end{array}$} & \multirow{2}{*}{$\begin{array}{l}\text { No. of households } \\
\text { as a \% of total } \\
\text { households in village }\end{array}$} & \multirow{2}{*}{$\begin{array}{c}\text { Mean value of } \\
\text { annual PCY (INR) }\end{array}$} & \multirow{2}{*}{$\begin{array}{l}\text { Mean value of daily } \\
\text { PCY (INR) }\end{array}$} & \multicolumn{4}{|c|}{ Income contribution from different sectors (\%) } \\
\hline & & & & Agriculture & Wages & NTFP & $\begin{array}{l}\text { Other } \\
\text { sectors }\end{array}$ \\
\hline Less than 500 & - & - & - & - & - & - & - \\
\hline $500-2,000$ & 10 & 1,751 & 5 & 20.5 & 19.4 & 43.5 & 16.6 \\
\hline $2000-5,000$ & 54 & 3,687 & 10 & 21.1 & 22.5 & 43.1 & 13.3 \\
\hline $5000-10,000$ & 27 & 6,529 & 18 & 40.5 & 13.4 & 27.7 & 18.4 \\
\hline $10,000-15,000$ & 5 & 13,374 & 37 & 46.3 & 9.6 & 19.2 & 25.0 \\
\hline $15,000-50,000$ & 5 & 15,941 & 44 & 58.0 & 2.8 & 12.5 & 26.7 \\
\hline
\end{tabular}

The important point, despite this diversity between the two non-displaced villages, is that the share of wages was less than one-fifth of the total income in both villages, pointing towards a high degree of self-sufficiency of households in meeting their subsistence needs. In contrast, in both the displaced villages covered by our study, the share of agriculture in case of the poorest households was found to be either negligible or actually negative (Table $5 \mathrm{c}$ and $\mathrm{d}$ ). It appears that these households have been attempting unprofitably to farm the poor quality land allotted to them after relocation, and cross-subsidising the losses on agricultural investments through earnings from wage labour or collection of forest produce.

Interestingly, in both displaced villages, the contribution of forest produce to total income is very high for the lowerincome brackets ( $72 \%$ for Jakhoda and $58 \%$ for Paira). This again reflects the higher effort and drudgery involved in
NTFP collection after displacement. Typically, the products being collected (like dauli, ber) sell for less than INR 2 per $\mathrm{kg}$; therefore, it remains a preferred livelihood activity only for households that cannot obtain adequate income from local or migratory wage labour. Moreover, after displacement, the collection of these products has devolved mostly to women and children, while the men spend their effort on searching for other wage opportunities as agricultural labourers or on government-sponsored wage works.

Perhaps the most striking finding of our study is the high dependence on wage labour, across all income brackets, of households displaced from the Kuno Sanctuary. The contribution of wage labour to livelihood was between onethird to half of the total income in both Jakhoda and Paira. This supports our main contention that displacement damaged traditional livelihoods and created a footloose population, 
Table 5c

Break-up of sectoral shares by household income categories: Jakhoda village

\begin{tabular}{|l|c|c|c|c|c|c|}
\hline \multirow{2}{*}{$\begin{array}{c}\text { Annual per } \\
\text { capita income } \\
\text { (INR) }\end{array}$} & $\begin{array}{c}\text { No. of households } \\
\text { as a \% of total } \\
\text { households in village }\end{array}$ & $\begin{array}{c}\text { Mean value of } \\
\text { annual PCY (INR) }\end{array}$ & $\begin{array}{c}\text { Mean value of daily } \\
\text { PCY (INR) }\end{array}$ & \multicolumn{3}{|c|}{ Income contribution from different sectors (\%) } \\
\cline { 5 - 8 } & & & Agriculture & Wages & NTFP & $\begin{array}{c}\text { Other } \\
\text { sectors }\end{array}$ \\
\hline Less than 500 & 5 & $-401^{*}$ & - & - & - & - \\
\hline $500-2,000$ & 20 & 1,407 & 4 & -8 & 32 & 72 \\
\hline $2000-5,000$ & 41 & 3,240 & 9 & 3 & 37 & 45 \\
\hline $5000-10,000$ & 27 & 6,814 & 19 & 7 & 26 & 27 \\
\hline $10,000-15,000$ & 5 & 11,570 & 32 & 1 & 93 & 7 \\
\hline $15,000-50,000$ & 2 & 18,448 & 52 & - & - & 13 \\
\hline
\end{tabular}

*Sectoral shares have not been calculated since average income is negative

Table 5d

Break-up of sectoral shares by household income categories: Paira village

\begin{tabular}{|c|c|c|c|c|c|c|c|}
\hline \multirow{2}{*}{$\begin{array}{l}\text { Annual per capita } \\
\text { income (INR) }\end{array}$} & \multirow{2}{*}{$\begin{array}{l}\text { No. of households } \\
\text { as a \% of total } \\
\text { households in village }\end{array}$} & \multirow{2}{*}{$\begin{array}{c}\text { Mean value of } \\
\text { annual PCY (INR) }\end{array}$} & \multirow{2}{*}{$\begin{array}{l}\text { Mean value of daily } \\
\text { PCY (INR) }\end{array}$} & \multicolumn{4}{|c|}{ Income contribution from different sectors (\%) } \\
\hline & & & & Agriculture & Wages & NTFP & $\begin{array}{l}\text { Other } \\
\text { sectors }\end{array}$ \\
\hline Less than 500 & 4 & $28 *$ & - & - & - & - & - \\
\hline $500-2,000$ & 14 & 1,438 & 4 & -7 & 40 & 58 & 9 \\
\hline $2000-5,000$ & 51 & 3,091 & 8 & -1 & 43 & 43 & 14 \\
\hline $5000-10,000$ & 24 & 6,500 & 18 & 17 & 35 & 26 & 23 \\
\hline $10,000-15,000$ & 4 & 12,030 & 33 & 8 & 48 & 37 & 7 \\
\hline $15,000-50,000$ & 2 & 17,804 & 49 & 15 & 52 & 2 & 32 \\
\hline
\end{tabular}

*Sectoral shares have not been calculated since average income is negligible

which depends on local and migrant wage labour as its chief source of livelihood. Given their low levels of literacy and lack of formal, marketable skills, this labour force occupies the lowest and most vulnerable rung of the wage market.

\section{Impact of displacement on poverty}

Our study used the official poverty line of the Government of India, which stands at INR 368 per capita per month for rural areas (Guruswamy \& Abraham 2006) and is referred to as the food poverty line ( $\mathrm{z}=$ INR 368$)$. This poverty line reflects the minimum threshold for survival, below which a household cannot even meet its subsistence calorific requirements. Setting aside for the moment various criticisms of the calorific-intake based method of calculating this poverty line, we first examined the poverty situation in the displaced and non-displaced households according to this definition. For an alternative, broader formulation of the poverty threshold, we used a basic-needs poverty line (pegged at INR 840 per capita per month), which reflects not just the food and calorie needs of a household, but also other essential non-food requirements like housing, fuel, health and education (Guruswamy \& Abraham 2006). Although there is some controversy about the precise level at which the basic needs poverty line is pegged, the fundamental fact that non-food basic needs should also be included in a definition of poverty finds wide acceptance (Deaton 2006). In this sense, the basic-needs poverty line used in this study provides an upper bound to the minimum subsistence requirements of a household.

Headcount ratio of poverty: The incidence of poverty (as measured by the HCR or the percentage of people subsisting below the poverty line) was distinctly higher in displaced households compared to non-displaced households. The HCR using the food poverty line was $6.3 \%$ in the non-displaced village of Bagcha and around $50 \%$ in Surde village, but was over $80 \%$ for both displaced villages. This finding is valid irrespective of the measure of income / consumption ${ }^{2}$ used. These comparative findings also hold true when the higher (or basic needs) poverty line was used (Tables $6 a$ and $b$ ), although the overall incidence of poverty was naturally found to be much higher in this case. Almost the entire population of Surde, Paira and Jakhoda villages was below the basic needs poverty line, highlighting the overall backwardness and underdevelopment of the study area.

Aggregate Poverty Index: The HCR is not a satisfactory measure of poverty, as it measures only the incidence of poverty, and is insensitive to the severity of poverty and inequality of income distribution among the poor (Deaton 2006). Given these limitations, we calculated an aggregate poverty index based on the Foster-Greer-Thorbecke (FGT) measure $^{3}$. This index is preferred because it is sensitive to the incidence and intensity of poverty among a community, as well as the degree of inequality among the poor. The FGT Index of poverty for the study villages, using the food and basic needs poverty lines and with $\alpha=2$ (measuring the squared poverty 
gap $^{4}$ ) has yielded the results outlined in Table 7.

Poverty among displaced households was found to be uniformly higher than poverty among the non-displaced households, whether viewed in terms of the number of people below poverty line, the severity of their poverty, or inequality among the poor. This result was found to be valid, irrespective of the chosen measure of income / consumption.

\section{Summary of findings}

The erstwhile inhabitants of the Kuno Wildlife Sanctuary were shifted from the resource-rich, but extremely remote forests, to a relocation site located only a few kilometers from their original place of residence. However, in terms of topography and resource endowment, the relocation site was drastically different from the Kuno Wildlife Sanctuary. Across 24 villages,

Table 6a

Headcount ratio using the food poverty line

\begin{tabular}{|l|c|c|c|}
\hline \multirow{2}{*}{} & \multicolumn{3}{|c|}{ BPL households as a \% of total households } \\
\cline { 2 - 4 } & For Y1* & For Y2* & For Y3* \\
\hline Bagcha & 6.3 & 17.5 & 6.2 \\
\hline Surde & 51.2 & 78.0 & 51.2 \\
\hline Jakhoda & 61.4 & 81.8 & 61.4 \\
\hline Paira & 63.8 & 80.9 & 72.3 \\
\hline
\end{tabular}

*Y1, Y2, Y3 are various measures of household income. Y1 denotes total annual consumption flows, or the monetised value of consumption obtained from physical, financial, natural, social and human capital stocks held by a household. Y2 denotes only cash income of a household.Y3 is analytically similar to Y2, but excludes money income created by external non-state actors like a local NGO.

Table 6b

Headcount ratio using the basic needs poverty line

\begin{tabular}{|l|c|c|c|}
\hline \multirow{2}{*}{} & \multicolumn{3}{|c|}{ BPL households as a \% of total households } \\
\cline { 2 - 4 } & For Y1* & For Y2* & For Y3* \\
\hline Bagcha & 46.3 & 56.3 & 46.3 \\
\hline Surde & 97.6 & 95.1 & 90.2 \\
\hline Jakhoda & 93.2 & 97.7 & 95.5 \\
\hline Paira & 93.6 & 97.9 & 95.7 \\
\hline
\end{tabular}

*Y1, Y2, Y3 are various measures of household income. Y1 denotes total annual consumption flows, or the monetised value of consumption obtained from physical, financial, natural, social and human capital stocks held by a household. Y2 denotes only cash income of a household.Y3 is analytically similar to Y2, but excludes money income created by external non-state actors like a local NGO. nearly 1,650 families, mainly hunters, gatherers and subsistence cultivators, had been subjected to a sudden and poorly planned shift to agriculture-based livelihoods in a drought-prone and highly degraded landscape. The relocation package was not informed by baseline data about pre-displacement livelihoods, and a 'one-size-fits-all' approach to livelihood restoration was taken. Loss of forest-based livelihood was not compensated through development of alternative, non-farm employment and livelihood options. As a result of the inadequacy of the relocation package and gaps in implementation, the largely self-sufficient forest-based livelihoods of the Sahariya gave way to precarious, mainly wage-based vulnerable livelihoods that left them insecure even in terms of food intake. Poverty in the displaced households has increased, and they have become chronically dependent on government relief.

Displacement caused the income to fall and poverty to intensify suddenly and sharply for the people displaced from the Kuno Wildlife Sanctuary. Instead of agriculture and forest produce collection, wage labour has become the most important source of income and livelihood. Average cash earnings of the displaced people are significantly lower even than the minimum subsistence income level indicated by the official calorie-based poverty line in India. When the official poverty line itself has been faulted for taking a very narrow view of the phenomenon of poverty, the fact that the average earnings of the displaced people do not even meet these minimalist criteria of well-being is a cause for deep concern. Even using a broader measure of income (with cash values being imputed for products obtained from nature), the average daily per capita income of the displaced people was barely equal to the national poverty line income level. This indicates poor access to many important nature-based products that these households earlier obtained for free from the wild.

An immediate impact of relocation was to give the displaced families greater access to liquidity (in the form of grants for house construction and for transport of household effects, and wage employment for land-clearing activities). This may have helped some of them to emerge briefly from their below-poverty-line status, as captured by the money-metric measures of poverty. However, in effect, most of this money was spent by the displaced households on consumption needs (including food and alcohol), and did not get converted to productive assets or investment in land or other income generating activities. Thus, as the flow of rehabilitationrelated funds tapered off, permanent loss of prior sources of cash income resulted in the re-entry of these households into

Table 7

Poverty estimates for displaced and non-displaced villages

\begin{tabular}{|l|c|c|}
\hline \multicolumn{1}{|c|}{ Village } & $\begin{array}{c}\text { FGT Index based on the Food Poverty Line } \\
(\mathrm{z}=\mathrm{INR} 368 ; \alpha=2)\end{array}$ & $\begin{array}{c}\text { FGT Index based on the Basic Needs Poverty Line } \\
(\mathrm{z}=\mathrm{INR} 840 ; \alpha=2)\end{array}$ \\
\hline Bagcha & 0.002 & 0.070 \\
\hline Surde & 0.064 & 0.321 \\
\hline Jakhoda & 0.190 & 0.433 \\
\hline Paira & 0.197 & 0.472 \\
\hline
\end{tabular}


income poverty. On balance, inadequate compensation for loss of social, financial, natural, human and physical capital left the displaced households worse off than before, resulting in increased vulnerability to chronic poverty.

Relocation also improved access of the displaced households to transport and communication infrastructure, due to the proximity of the relocation site to the mainstream economy. However, given the loss of established livelihood, unfamiliar social and economic environment, and sudden irrelevance of established coping strategies, the terms at which the displaced households could interact with 'mainstream' forces like markets and the media were highly disadvantageous. Thus, these potential advantages do not appear to have translated into actual livelihood gains.

For a majority of the people displaced from Kuno, resettlement resulted in chronic food insecurity and increased vulnerability to disease and mortality, and triggered distress responses like migration. Food security declined due to a combination of reduced income, poor agricultural output, loss of access to wild fruit, vegetables, roots and berries, and loss of access to wild meat due to sharply reduced opportunities for hunting. Increased vulnerability to hunger and starvation is not just an indicator of severe economic distress, but also has serious implications for the long-term ability of these families to move out of chronic poverty. As their diet is often inadequate and low in nutrient content, the displaced families are very vulnerable to disease. Moreover, since they spend nearly their entire income on provisioning food, even a small health crisis in the family often pushes them into a debt spiral or results in distress migration or sale of assets to meet treatment costs.

In this grim scenario of breakdown of their entire system of livelihood, the displaced Sahariya are forced to depend increasingly on relief provided by the state. However, the poverty of the displaced people is matched by poverty of governance in this remote and neglected region, which is marked by massive inefficiencies in the delivery of vital services like education and health. Rampant corruption and rent-seeking collude to keep these facilities, as well as targeted relief (housing, old-age pension, food-for-work, employment guarantee, mid-day meals, anganwadi and other services of the welfare state) beyond the reach of the most vulnerable and deserving households.

\section{THE BHADRA EXPERIENCE}

\section{Methodology}

This section is based on information obtained from secondary sources including academic articles, published reports and grey literature on the resettlement and rehabilitation of villages from the Bhadra Wildlife Sanctuary. In addition, detailed, semi-structured interviews were carried out in the summer of 2007 with various stakeholders in the Bhadra Land Acquisition and Resettlement and Rehabilitation (LA and R\&R) Project of the Government of Karnataka. The majority of households at the two rehabilitation sites, MC Halli and Balehalli-Kelagur were interviewed. This included interviews with holders of 1 acre, 3 acre and 5 acre plots at the MC Halli relocation site, and similarly interviews with 5 acre and 10 acre plot holders at the Balehalli-Kelagur relocation site. Separate interviews were held with women, and with erstwhile landless labourers, individually as well as in groups. The objective of these interviews was to collect quantitative and qualitative data about the livelihood outcomes of resettlement and rehabilitation. Detailed information was also collected on the exact process followed by the authorities for carrying out land acquisition and rehabilitation, and the nature of the displaced households' engagement with the authorities. In addition, we held several rounds of discussions with the district authorities responsible for land acquisition, Forest Department officers and staff involved in resettlement and rehabilitation, as well as office bearers of voluntary organisations involved in the entire process.

\section{The area and the people}

The Bhadra Wildlife Sanctuary (Table 8a) is located in the hilly Malnad region of Karnataka. Within Karnataka, the Western

Table 8a

Bhadra wildlife sanctuary at a glance

\begin{tabular}{|c|c|}
\hline Location & $\begin{array}{l}\text { Chikmagalur and Shimoga districts, Karnataka } \\
75^{\circ} 15^{\prime} \text { to } 75^{\circ} 50^{\prime} \mathrm{E} \text { and } 13^{\circ} 25^{\prime} \text { to } 13^{\circ} 50^{\prime} \mathrm{N}\end{array}$ \\
\hline Total area & 492 sq. $\mathrm{km}$. \\
\hline Current legal status & $\begin{array}{l}\text { Wildlife sanctuary notified under the Wildlife Protection Act, 1972; } \\
\text { Initial notification in 1974; Final notification in } 1998\end{array}$ \\
\hline History and year of establishment & $\begin{array}{l}\text { 1. Reserve forest between } 1912-1950 \\
\text { 2. Game sanctuary in } 1951 \text { (parts) } \\
\text { 3. Bhadra wildlife sanctuary in } 1974 \\
\text { 4. Project tiger reserve in } 1998\end{array}$ \\
\hline Major vegetation types & Dry and moist deciduous forests (bamboo), evergreen montane grasslands, teak plantations \\
\hline Conservation significance & $\begin{array}{l}\text { The Western Ghats are a global biodiversity hotspot, with high levels of biological productivity, } \\
\text { species diversity, and endemism }\end{array}$ \\
\hline
\end{tabular}


Ghats or Malnad includes the districts of Chikmagalur, Hassan, Kodagu, Shimoga and the uplands of Dakshina Kannada, Uttara Kannada, Udupi, Belgaum and Dharwad districts. The region receives rainfall in the range of $1,000 \mathrm{~mm}$ to 2,500 $\mathrm{mm}$. Much of the dense rain forest area of the state lies in this region, which is rich in teak, rosewood and bamboo. Important commercial crops of Malnad include coffee, areca nut, pepper, cardamom and rubber. Even as Nagarhole National Park and Bandipur Wildlife Sanctuary are the better known Protected Areas of Karnataka, it is believed that the quality of the forest is much better in Bhadra. The Bhadra Wildlife Sanctuary has been identified by biologists as a 'biodiversity hotspot', with high levels of biological productivity, species diversity and endemism. Fauna in this region represent $30 \%$ of all Indian mammal and bird species (Karanth and Karanth 2007). The Western Ghats are home to several larger vertebrate species, some of which have global conservation significance due to their rarity, endemism, habitat-specificity, susceptibility to commercial exploitation, or proneness to come into conflict with human societies. The Ghat forests occur as a fragmented strip within a larger landscape matrix consisting of crops, tree plantations and montane grasslands - also known as 'shola' grasslands. Vegetation in the Bhadra Wildlife Sanctuary comprises of wet evergreen forests and moist deciduous forests that are dominated by bamboo.

The creation of the Bhadra reservoir by damming River Bhadravathi in the 1960s completely cut off the two main roads running through this area, which used to connect Chikmagalur city to towns in the Shimoga district. As a result, the wildlife rich Muthodi valley became isolated and flora and fauna began to flourish in the region. The initial Notification declaring Bhadra Wildlife Sanctuary was issued by the State Government vide G. O. No. AFD 25 FWL 74, dated 6 September 1974 under the Wildlife Protection Act, 1972. The final Notification was issued in the year 1998 vide G. O. No. FEE 58 FWL 96, dated 9 March 1998. In view of the ecological importance and the potential to support high density faunal populations, this sanctuary was upgraded to the status of Project Tiger Reserve by the Government of India on 19 November 1998.

\section{Conservation history of Bhadra wildlife sanctuary}

In the early 1900 s, the area of the present-day Bhadra Sanctuary was sparsely populated, and reportedly had 'a village with 88 people and 186 cattle occupying an area of 4.19 sq. km' (Karanth \& Karanth 2007, quoting an anonymous, unpublished report of 1917). The population inside the Bhadra forests increased gradually during the colonial period, when settlers were brought in by the Imperial Forest Department, reportedly to cut trees and make charcoal for the development of the railways nearby (Anon 2002), and this population growth continued after India's independence. The closest town for most of the villages inside Bhadra was Narasimharajapura (or NR Pura), a sub-divisional headquarter town that provided the people with a market, banks, higher education and health facilities. The Bhadra villages were linked to NR Pura by an all-weather road, and by all accounts the people in these villages were well-networked, and not isolated households with a forest-dependent, self-sufficient, subsistence agriculturebased economy.

Despite Bhadra's status as a Protected Area and a Project Tiger Reserve, the human population living inside it continued to grow, but there appears to have been a shift in the class composition of this population after the late 1960s, following construction of the Bhadra reservoir. The reservoir led to breakdown of communication and transport links of these villages from NR Pura (Sreekantaiah \& Subramanya 1992), and most of the affluent landholders migrated out of the forest, to set up alternative residences in the nearby towns like NR Pura and Chikmagalur. They, however, continued to hold on to their land inside the forest, which they leased out to small and marginal farmers or cultivated using a class of agricultural labourers. Thus, even as legal landholdings remained static, the profile of the average households actually living inside the forest in the 16 villages changed gradually during the next three decades (1960s to 1980s) from self-cultivating agriculturalists to agricultural labourers and share-cropping tenants. These dynamics were fairly important in determining the eventual outcome of the village resettlement project.

According to a recent estimate (Karanth et al. 2006), the total number of individuals inhabiting the park till recently was 4,000 (that is, 8.1 people, including adults and children, per sq. km). Households across all villages hunted game, grazed livestock, and collected firewood, timber and forest products (Karanth 2007). Development activities are said to have slowed down or nearly halted when the Bhadra reservoir was built in the 1950s and 1960s. This reservoir isolated the settlements in the sanctuary, limiting infrastructure development. Infrastructure development suffered a further setback with the declaration of a large part of this area as the Bhadra Wildlife Sanctuary in 1974.

Declaration of the Bhadra Wildlife Sanctuary as a Project Tiger Reserve resulted in growing attempts by the Karnataka Forest Department to 'manage' this Protected Area scientifically, and to reduce human disturbances within the area of the Sanctuary. According to the Forest Department, pressures on flora and fauna in the Bhadra Wildlife Sanctuary emanated from multiple sources, including the proposed irrigation / river linking and mining projects, and commercial extraction of bamboo and other timber species. However, resource extraction by locals, as well as incidents of poaching and forest fires, were the most frequent and immediate threat, and also the ones that seemed most simple to handle. The resettlement of villages from Bhadra was seen as a measure that could improve the ecological sustainability of the Protected Area, while also addressing severe human wildlife conflicts (crop raiding, property loss, livestock predation) that occurred frequently within this park. In this sense, the resettlement of villages from this Protected Area was posited as a 'win-win' solution to the problems of conservation and development in the Bhadra Wildlife Sanctuary. 
Attempts to relocate villages had been made sporadically in Bhadra since the early 1990s, but were resisted by the people due to poor experiences of other resettled people nearby, especially those resettled during the construction of the Bhadra dam and reservoir. By the end of the 1990s, conflicts and confrontations between the local people and the Forest Department intensified, and instances of damage to the forest by the people (through hunting, poaching and forest fires) began to escalate (Karanth 2007). Official attempts to impose conservation regulations on the villagers against illegal hunting, grazing and timber removal caused great resentment. Villagers had allegedly used extreme measures like arson systematically and deliberately to register their disapproval of the extant forest conservation laws and implementation methods of the forest authorities. It was against this backdrop that the Bhadra Land Acquisition and Resettlement and Rehabilitation Project was undertaken.

\section{Justification for displacement}

The documents pertaining to the Bhadra Land Acquisition and Resettlement and Rehabilitation Project do not explicitly set out the scientific basis for the decision to relocate villages. The Forest Department representatives interviewed by this author were emphatic that the presence of villages inside the sanctuary was highly detrimental to wildlife. Instances of forest damage, poaching, forest fires and illegal extraction of forest resources were said to have been widespread before the relocation of villages, and human-wildlife conflicts were supposedly frequent and fairly severe. However, no official surveys, studies or reports of the Forest Department are available to support this claim, and no other studies by independent researchers have been cited in the Relocation Plan or other official documents to justify the need for village relocation.

However, the published literature on Bhadra Wildlife Sanctuary as well as literature generated by local voluntary organisations, wildlife researchers and individuals does point towards the deleterious impact of humans on wildlife in Bhadra. A smaller sub-set of this literature also dwells on the difficult living conditions of the people living inside the sanctuary, and on damage caused frequently to crops, property and even lives, by wildlife.

'Human Disturbance' in Bhadra Wildlife Sanctuary: There were 16 villages inside the Bhadra Wildlife Sanctuary, comprising of 736 families. Several recent studies have examined the negative impacts of human activities on animal and plant communities inside the reserve. These activities include biomass extraction, livestock grazing, deliberate arson and removal of wood. Karanth \& Karanth (2007) estimated that the combined human activities had directly affected $8-10 \%$ of the sanctuary by altering $23.7 \mathrm{sq}$. $\mathrm{km}$ of the forest near the villages.

Livestock grazing was said to have been widespread in the Bhadra Wildlife Sanctuary, and recent studies indicate that increased livestock densities have reduced forage availability, degraded forest vegetation, changed plant composition, and led to declines in wild herbivores due to competition in Bhadra. All households living inside the sanctuary reportedly collected fuel wood from the forest and quantities ranged from 2,190 to 22,140 $\mathrm{kg}$ per week (Karanth et al. 2006). This local scale collection is estimated to have directly affected food availability for wildlife as well as regeneration and recruitment of plant species.

Human-wildlife conflict: Nearly $73 \%$ of the households living inside Bhadra Wildlife Sanctuary prior to resettlement are said to have regularly lost $15 \%$ of their annual harvest to crop-raiding by elephants and ungulates. These households are also reported to have lost $11-25 \%$ of their livestock to carnivores (Karanth et al. 2006). Retaliatory killing of elephants and big cats was reported to be a serious conservation problem in this Protected Area.

\section{Relocation of villages from Bhadra wildlife sanctuary}

The Bhadra Land Acquisition and Resettlement and Rehabilitation Project was initiated in 1999, by the Government of Karnataka, and involved the relocation of 419 families to a location on the periphery of the Bhadra Wildlife Sanctuary (Table 8b).

An agreement was reached between the Government of India and the Government of Karnataka, whereby the cost of acquisition was to be borne by the Government of India and the rehabilitation cost by the Government of Karnataka. The final cost-sharing arrangement is depicted in Table 9.

\section{The relief and rehabilitation package and relocation sites}

The relief and rehabilitation package to be administered to the households displaced from Bhadra Wildlife Sanctuary

Table 8b

Details of land acquisition (Figures derived from Karnataka Forest Department 1999)

\begin{tabular}{|l|c|c|}
\hline \multicolumn{1}{|c|}{ Villages } & $\begin{array}{c}\text { Families } \\
\text { rehabilitated }\end{array}$ & $\begin{array}{c}\text { Land acquired } \\
\text { (in acres) }\end{array}$ \\
\hline Hebbe & 97 & 99.7 \\
\hline Madla & 159 & 250.15 \\
\hline Hipla & 98 & 143.46 \\
\hline Kesave & 60 & 85.25 \\
\hline Muthodi & 36 & 34.23 \\
\hline Karuvane & 52 & 106.00 \\
\hline Madla-Waddihatti & 51 & 17.62 \\
\hline Hebbe-Kurkulmane & 7 & 5.00 \\
\hline Bidare & 12 & 7.20 \\
\hline Shiragola & 2 & - \\
\hline Balegadde & 20 & 33.22 \\
\hline Mutt & 24 & 17.49 \\
\hline Hunasekatte & 15 & - \\
\hline Heggarmattuvane & 68 & 1.1 \\
\hline Kanchagar & 736 & -861.29 \\
\hline Madhuguni & & \\
\hline Total & 28 & -19 \\
\hline
\end{tabular}


was approved by the State Government vide Government Order No. RD.69.REH.97, dated 28 March 2001 (hereafter referred to as the GO of 2001) and is summarised in Table 10.

As per the GO of 2001, nearly 1300 acres of cultivable land was to be made available to the displaced households at the resettlement site. The main site identified for resettling the people from Bhadra Wildlife Sanctuary was a large plot of 905.47 acres, adjacent to the village of Malala Chenannahalli (MC Halli), located on the Bangalore-Shimoga stretch of the National Highway No. 206, between Tarikere and Bhadravathi. This site used to be a part of the West Hadikere State Forest, which was de-notified during the 1960s under the Grow More Food Campaign, and leased out to a sugar mill for cultivation of sugarcane. The lease expired in the late 1980s, and subsequently, in the early 1990s the area was earmarked for resettlement of the Bhadra villages. The second resettlement site was located near Handi village, at a place called BalehalliKelagur, nearly $23 \mathrm{~km}$ from Chikmagalur town. The site was a part of the Revenue Department land, on which the Forest Department had raised Acacia plantations under the Social Forestry Programme since 1974. Nearly 433 acres of dryland was available for resettlement at Balehalli-Kelagur, and this was earmarked for 109 families.
Against the proposed 16 villages to be relocated, till August 2007 , only 10 villages had actually been shifted out. Of the remaining six villages, three villages continued to remain inside the Bhadra Wildlife Sanctuary, while the remaining three were awaiting relocation once specific problems with their shifting were sorted out. The three villages still inside Bhadra (Bidare, Madhuguni and Balegadde) are at a geographical location that distinguishes them from the villages relocated so far. These three villages are situated on the south-western tip of the sanctuary, across the River Bhadra. Thus, they form a distinct pocket, which did not have too many linkages with the resettled villages, and have an economy and lifestyle that is also distinct. Their level of forest dependence is quite high, and at present, the residents of these villages appear to be vehemently opposed to the idea of relocation. For now, the approach of the Forest Department appears to be, to allow them to continue residing inside the sanctuary, and apparently, no serious attempts are being made at present to identify alternative land for them or to convince them to move out of Bhadra.

\section{Impact of displacement on livelihoods}

The households living inside the Bhadra Wildlife Sanctuary depended for subsistence on a combination of agriculture,

Table 9

Estimated and revised project cost (Source: Karnataka Forest Department 1999)

\begin{tabular}{|l|l|l|l|}
\hline & \multicolumn{1}{|c|}{ Cost of acquisition (INR) } & \multicolumn{1}{c|}{$\begin{array}{c}\text { Cost of resettlement and } \\
\text { rehabilitation (INR) }\end{array}$} & \multicolumn{1}{c|}{ Total cost (INR) } \\
\hline Borne by & Government of India & Government of Karnataka & \\
\hline Original estimated cost & 7.02 crores & 5.74 crores & 12.76 crores \\
\hline Revised estimates & 13.0 crores & 4.65 crores & 17.65 crores \\
\hline
\end{tabular}

*INR 1 crore $=$ INR 10 million

Table 10

The Bhadra relief and rehabilitation package (Source: Karnataka Forest Department 1999)

\begin{tabular}{|l|c|}
\hline \multicolumn{1}{|c|}{ Details } & $\begin{array}{c}\text { Amount } \\
\text { (INR in lakhs)* }\end{array}$ \\
\hline Ex gratia payment for displaced families (736 families ) & 152.3 \\
\hline Cost of infrastructure at rehabilitation centre & 10.00 \\
\hline Construction of school building & 51.00 \\
\hline Road network including drainage & 6.00 \\
\hline Burial grounds \& recreation park & 5.00 \\
\hline Shopping complex & 1.00 \\
\hline Bus Shelter & 3.00 \\
\hline Temple & 33.00 \\
\hline Water supply & 100.00 \\
\hline Providing Electricity & 36.80 \\
\hline Transportation cost at INR 5000/- per displaced family (736 families) & \\
\hline Dispensary and veterinary dispensary & \\
\hline Total & \\
\hline Contingency \& administrative overheads at 10\% of total & \\
\hline Total & \\
\hline
\end{tabular}

*INR 1 lakh = INR 100,000 
forest-based extraction and processing of resources. The shift to an area outside the sanctuary reduced their access to forest resources, and made agriculture their prime source of livelihood. Thus, returns from agriculture and new non-farm enterprises at the relocation site were required to be fairly high, to compensate for the loss of other livelihood options like livestock rearing and trapping, and for loss of resources and raw materials that were earlier obtained for free from the forest, but now have to be purchased at the relocation site (e.g., fuel and fodder).

After relocation, each displaced household has received cultivable revenue land, a housing plot, along with various infrastructure facilities at the relocation site, as well as cash compensation for assets lost at their original place of residence. Each landless family that was shifted to MC Halli was given a house, constructed at a cost of INR 42,000 under the Centrally Sponsored Scheme of the Union Government, the Indira Awaas Yojana. Households with larger landholdings inside Bhadra were given only housing plots, on which they undertook construction of houses using their compensation money. The payment of cash compensation was substantial, and Table 11 outlines the profile of compensation amounts received by the households displaced from Bhadra. Both relocation sites (MC Halli and Kelagur) have electricity, pumped water, markets, schools, hospitals and access to public transport, and are welllinked to other major towns and cities.

For the most important livelihood source, land, we found that against the total acquisition of 861 acres by the state, nearly 1,300 acres of cultivable and irrigable land was made available at the resettlement site. In fact, relocation appears to have brought about a progressive shift in land distribution, since it involved a grant of one acre of cultivable land to landless families, which formed a majority of the displaced households. The bigger landholders also appeared to have gained, receiving 5-10 acres of good quality land in a more mainstream area next to an important National Highway, along with due compensation for all immovable assets. Moreover, and unlike Kuno, the quality of land received by the people relocated from Bhadra was very high; the MC Halli site had prime, irrigated agricultural land that was under sugarcane cultivation till the early 1990s. Even the land at Kelagur, the second relocation site, was fairly suitable for coffee cultivation, although it required relatively higher levels of investment and a significantly longer gestation period.

In addition, a range of socioeconomic infrastructure and development facilities have been provided at both resettlement sites, which seems to have made a significant positive contribution to the overall welfare of the relocated people. High cash compensation amounts also appear to have improved the living standard of many displaced families, who show visible signs of prosperity (private vehicles, larger and more expensive houses, better schooling for children, etc.). Here again, the contrast with Kuno - where compensation for condemned assets is yet to be paid (10 years after displacement) - is palpable. Karanth (2005) reports that during 2002-2005, positive developments at the relocation site include establishment of a public water system, phones and television sets, solar lights and cooking gas stoves in both villages, as well as a new school and electricity connections in MC Halli. She finds that school enrollment has increased, as has participation of the displaced households in local politics in the relocation area. In terms of livelihoods too, evidence is cited of resettled families succeeding in agriculture, and starting new service sector occupations like restaurants, grocery stores and other retail activities.

Our interviews with people at MC Halli as well as Kelagur found them slightly more circumspect. They felt that relocation has brought about far-reaching changes, positive as well as negative, in their lives. Significant adjustments had to be made to the new circumstances, especially to the fact that after relocation, most requirements of the household have to be purchased and cannot be obtained gratis from nature. The overall need for cash income has increased, even while the potential sources of such income may have remained static. The sudden transition from the subsistence mode of production to a predominantly market-based economy has been quite difficult, especially for poor households and for vulnerable groups like women. A few landless households have reportedly been unable to adjust, and have sold their lands and moved to other locations. By and large, however, most resettled families appear to be satisfied with their overall condition after the move from Bhadra. This is also reflected in the voluntary withdrawal or dismissal by the court of a majority of legal complaints that were filed against the process of land acquisition and resettlement. Interestingly, the proportion of people who expressed dissatisfaction with their rehabilitation is reported to have increased between 2002 and 2006, although this may be partly due to increased expectations and higher political awareness of the relocated people (Karanth 2007).

Evidence from the second relocation site (Kelagur) is less equivocal, and some households here do not appear satisfied with their rehabilitation. Moreover, the land allotted to displaced families in Kelagur is unirrigated, and more suitable for coffee cultivation, which has a longer gestation period. In the interim, many households have had to depend on wage labour (mainly in neighbouring coffee plantations or nurseries) for their livelihoods (Karanth 2007). However, we observed a

Table 11

Profile of compensation paid at Bhadra

\begin{tabular}{|l|l|}
\hline Minimum compensation amount & $\begin{array}{l}\text { Approx. INR 35,000 (house construction grant, transportation allowance and compensation for } \\
\text { condemned housing at original site) }\end{array}$ \\
\hline Maximum compensation amount & Approx. INR 5,000,000 (received by a coffee planter who had large landholdings inside BWLS) \\
\hline Average compensation amount & Between INR 100,00 and INR 400,000 per household \\
\hline
\end{tabular}


divergence of opinion among displaced households at Kelagur regarding the extent of livelihood distress, and found that the disgruntled households have not been able to mobilise others to generate any sustained resistance.

\section{COMPARATIVE ANALYSIS - KUNO VS BHADRA}

The relocation of villages from Kuno and Bhadra sanctuaries followed nearly identical timelines, starting around 1999 and ending around 2002. The two relocation projects were funded (fully or partly) under the same Centrally Sponsored Scheme, the Beneficiary Oriented Scheme for Tribal Development, and oversight at the level of the Government of India was provided by the same agency (Project Tiger, Ministry of Environment and Forests). In both cases, the overall task of village relocation and rehabilitation was carried out on the ground by handpicked officers of the State Forest Department, with fairly similar sets of constraints and advantages.

However, the livelihood outcomes for relocated families were radically different in Kuno compared to Bhadra, as outlined in the previous two sections. Even before their displacement, the Sahariya adivasi of Kuno, Madhya Pradesh, were a socially, politically and economically marginalised community, whose lives and livelihood were linked intricately to their ecological base. Inadequate attention was paid to this while designing and implementing a suitable rehabilitation package for the Sahariya. As a result, their material condition has deteriorated after displacement, due to loss of livelihood diversification opportunities and alienation from their natural resource base. Displacement, therefore, has resulted in rapid proletarianisation and pauperisation of these households, and their 'integration' into the national 'mainstream' has occurred at highly disadvantageous terms.

On the other hand, the households displaced from the Bhadra Wildlife Sanctuary consisted of relatively heterogeneous, but generally less marginalised social groups, which occupied a prominent place in the local politics and economy of Karnataka. The share of agriculture in the pre-displacement livelihood of these households was relatively higher, and dependence on forest-based livelihoods relatively less than in Kuno. Bhadra also seems to have benefited from the prior presence of dedicated local voluntary organisations, which worked painstakingly to making the relocation a success. Consequently, the relocation package and process was far more effective in mitigating the potential impoverishment risks of these households, which have negotiated and obtained better post-displacement livelihood outcomes than the Sahariya of Kuno.

\section{Standard of living}

Income levels and the standard of living among the people displaced from Kuno are pitifully low. Rampant food insecurity and distress migration are common among the relocated households (Kabra 2003; Bunsha 2005). Vulnerability to disease is very high, and instances of acute malnutrition and even starvation deaths have been reported from the displaced villages in drought years (Arun 2005). The total number of households reporting agriculture as their primary livelihood has declined in displaced villages for all crops, and average livestock holdings have declined to less than $50 \%$ of the predisplacement levels. Average food grain production has fallen to only about $10 \%$ of the pre-displacement levels, due to the poor quality of land at the relocation site and breakdown of traditional farm practices. Therefore, the level of proteins and other nutrients in the diet has fallen drastically, as wild meat, milk and dairy products from own livestock have nearly disappeared from the diet (Kabra 2007).

At less than INR 10 per day, the average per capita income of displaced households is significantly lower than the poverty line. These households are unable to purchase from the market many essential items that they earlier obtained for free from the forest. The overall asset holding pattern has also shown adverse movement after displacement, with fewer households reporting access to means of transport and entertainment (Kabra 2008). The degree of inequality has increased after displacement, with a clear divide between the few households that received land adjacent to the river and the majority that received rocky upland farm tracts. The living standard of the latter group has plummeted after relocation, with dependence on wage employment, and often distress migration rising sharply.

On the other hand, the households relocated from Bhadra enjoy higher standards of living at both relocation sites (Karanth 2007). Almost all the people we interviewed live in concrete houses, and now possess a range of assets like television sets, telephones, bicycles and motorbikes, furniture and basic electronic appliances. Relocated households with one acre landholdings (who were erstwhile landless farmers) received spacious pucca houses constructed by a state agency, while households with larger landholdings constructed their own houses. Interviews with relocated families at MC Halli revealed that a large number of the one-acre landholders have managed to build additional rooms to their houses, and have also constructed sheds for their livestock. Most families with adequate family labour keep livestock and manage to sell some milk to a local dairy. All relocated households have access to piped drinking water, as well as to public and private schools and hospitals.

Their land at MC Halli is high-quality, irrigated farmland, on which they grow a combined crop of sugarcane and paddy. A number of relocated families have been able to set aside a part of their land for areca plantations, which will start yielding a steady income after five years. Most households interviewed by us grow enough rice on their land to meet their own requirements throughout the year. Many of these families have educated children who have taken up a variety of semi-urban, non-farm livelihoods in or around MC Halli (carpentry, auto rickshaw driving, electricians) that supplement their farm income. A number of relocated families have taken insurance policies and are able to regularly pay their premium, demonstrating a steady cash flow in the household. The women from many households at MC Halli have become members in 
self-help groups and are able to save small sums of money, and frequently borrow from these self-help groups to meet expenses related to children's schooling and health. The major points of discontent seem to be low availability of fuel wood in the area, which forces them to spend money on cooking gas cylinders or purchase fuel wood from the market. They also find the climate in the new area less pleasant than inside Bhadra, but on balance they are reconciled to the new area, given its additional facilities and infrastructure.

\section{Payment of compensation}

In Kuno, the payment of compensation for immovable assets acquired during displacement began ten years after physical relocation of villages, and has been concluded recently (in 2009). The relatively affluent displaced households have lobbied regularly with the Forest Department in the intervening years to speed up this process, but were not successful due to low political clout and generally poor community organisation. In Bhadra, in contrast, government officers in charge of relocation (the Divisional Forest Officer and the District Collector) ensured that the final compensation award was speedily delivered and legally watertight. The compensation amount was high enough to be acceptable to a majority of the displaced families. This is reflected in the fact that very few objections were received by the Land Acquisition Officer on the final award.

Another reason for the high value of compensation received by the relocated families was their own awareness levels and political clout, which provided them with a higher-than-average ability to bargain for a good compensation package. Some families were aware of the intricacies of the land acquisition process, due to their prior experience with displacement during the construction of the Bhadra dam and reservoir. Such families managed to sub-divide their lands in anticipation of impending land acquisition, and registered a sufficiently high value of their sub-divided land in the revenue records, for this value to serve as a benchmark. Familiarity with state processes in general, and specifically with land acquisition and resettlement and rehabilitation processes, enabled the people displaced from Bhadra to ensure that fair and just compensation was promised to them and then actually delivered.

\section{Community organisation and cohesiveness}

The contrast between the households relocated from Kuno and Bhadra is equally sharp when one looks at the degree of organisation of the community, in the face of displacement threats. In Kuno, there was virtually no organised protest during the late 1990s against the government's decision to acquire their land for the Lion Reintroduction Project. Before and during the resettlement process, local opinions varied on the question of resettlement. Some adivasi households expressed apprehensions with regard to relocation, but most of them were willing to leave in view of the promised facilities, especially the large cash grant being offered. Some non-adivasi farmers, who were cultivating vast stretches of encroached land inside the Sanctuary and stood to lose this land as a consequence of displacement, were strongly opposed to relocation, but were unable to mobilise public opinion. In fact, two villages (Khallai \& Barrer), which were scheduled to be relocated in 2000-2001, actually advanced their shift and began squatting at the relocation site as early as 1999, in the hope of receiving cash grants and their preferred patches of land. The exodus of other villages followed soon after, thereby, shoring up the Forest Department's claim that the Kuno relocation was entirely 'voluntary' in nature.

Dissatisfaction of the resettled people was manifested subsequently in instances of symbolic reoccupation of their original villages inside the sanctuary. The first instance was in 2001, when 35 families of Paira village reoccupied their original village. In 2003, 40 families from Nayagaon village did the same. In 2004, Nayagaon (70 families); Pipalbaodi (55 families); Palpur (30 families); Basantpura (25 families) and Paira (40 families) returned to their original villages inside the sanctuary. The displaced people seem to have used this move to force the Forest Department to attend to their most immediate problems, and also to earn livelihood opportunistically through collection of forest produce from the sanctuary during periods of extreme stress such as drought. However, due to lack of cohesion among the displaced households, none of these efforts were serious enough to make a significant impact. The Forest Department tackled these token protests successfully on each occasion, using a combination of carrot-and-stick measures targeted at select individual 'leaders' and 'problematic' individuals, without any major repercussions on the sanctuary itself (Kabra \& Sharma 2007).

In Bhadra, in contrast, the degree of community cohesiveness and organisation was much higher. When the Bhadra project for acquiring land and relocating villages began in the late 1990 s, a majority of the villagers opposed the resettlement in an organised manner, under the banner of the Bhadra Aranya Horata Samithi. They approached the High Court and filed cases opposing the proposed project, and were vocal and demonstrative in their opposition to the Forest Department. This organisational strength was derived in a large part from the caste composition of the relocated families and their past exposure to the mainstream. This enabled them to identify and obtain good quality land and good terms of compensation and a dialogue with political leaders and bureaucrats, to push their agenda effectively. In times of crisis, it also enabled them to protest at various levels, to bring the Forest Department to the negotiating table.

\section{CONCLUSION}

In this article, we have documented in detail from two sites, the response of the local community to the acquisition of their land, and the associated loss of livelihoods, by the state for the 'public purpose' of conservation. The Kuno and Bhadra experiences serve to highlight the advantages as well as limitations of the strategy of 'conservation via displacement'. 
The foremost lesson from these experiences is that displaced people who lack information, organisation and political clout (as, for instance, the Sahariya in Kuno) are poorly positioned to access their de jure right to compensation and rehabilitation. Such households / communities are less likely to be able to mitigate the livelihood risks inherent in displacement, and tend to obtain negative post-displacement livelihood outcomes. On the other hand, relatively more powerful and well-connected households (as, for instance, in Bhadra, or among the non-tribal households in Kuno) are more likely to 'work' the system to their advantage and obtain benign or positive livelihood outcomes from the same set of implementing agencies.

In general, purely managerial, project-based approaches to resettlement and rehabilitation tend to focus excessively on the goodwill and performance of a few 'good' officers, and do not factor in the political processes that help or hinder state institutions in delivering good governance. The Bhadra experience highlights that even what appears, prima facie, to be efficient management of resettlement and rehabilitation by a 'committed' officer is in effect a deeply political process. Thus, the same 'wise practices' in relocation and resettlement may generate vastly different results in different locations, depending on the political and social capital enjoyed by the displaced households. It is, therefore, critical to develop systemic checks and balances and create a policy environment that allows marginal groups like Adivasis and women to find effective voice. The Kuno-Bhadra comparison suggests a strong case for the long-term involvement of civil society actors like voluntary groups and community organisations in implementing rehabilitation programmes among marginalised communities. Sustained community mobilisation by such organisations can alter local power dynamics gradually in favour of marginal groups, thus enhancing their chances of actually obtaining their de jure rights to compensation, rehabilitation and livelihood restoration. In this context, the amendments to the Wildlife Protection Act effected in 2007, and more importantly, the enactment of the Scheduled Tribes and Other Forest Dwellers (Recognition of Rights) Act are welcome moves. Both enactments firmly reinforce the idea that involuntary displacement should be minimised and co-existence options should be explored wherever possible. These legislations also set out in some detail the precise circumstances under which relocation of people from PAs can be undertaken, and reiterate the principle of fair compensation aimed at livelihood restoration.

Institutional theory suggests that 'operational rules' that determine post-displacement livelihood outcomes arise from the interaction of de jure state structures with de facto systems of localised practice, which in turn reflect local social power (Robbins 2000). The implementation effectiveness of state agencies responsible for land acquisition, payment of compensation and rehabilitation is therefore not likely to be uniform across all displaced households. It will, instead, be 'adapted and curved around the contours of local power' (Robbins 2000: 427). Typically, institutions like the Forest Department, staffed at the middle and lower level by people drawn from the local area, are highly entrenched in local power dynamics. The pre-existing nature of the social capital that informs their interactions with forest-dwelling communities also 'follows existing lines of casted, classed and gendered power and reproduces persistent elements of local politics' (Robbins 2000: 424).

Thus, in the case of Kuno, where the majority of the displaced people were from the politically marginal Sahariya Adivasi community, the Forest Department could get away with delivering only a fraction of the de jure rights of the displaced community, without fear of strong local protest. It repeatedly diffused potentially tense situations by intimidating the less powerful, and distributing favours among the 'leaders'. In Bhadra, on the other hand, where the displaced people belonged to communities that were politically more empowered and included people well-connected with the local elite, the de facto operational rules binding the Forest Department staff were far more stringent. Thus, its 'sensitivity' to the needs of the displaced community was significantly higher.

The Kuno-Bhadra comparison shows that historically marginalised groups like the Adivasis can expect, at best, partial delivery of compensation and rehabilitation, unless the overall institutional framework, design and process of delivery of land acquisition and resettlement projects changes drastically. Moreover, these are likely to be given not as a right but as a gift or favour bestowed by 'benevolent' officials, or as palliatives that are offered to select individuals, to keep down the threat of organised protest. This has important social justice implications, especially for the highly vulnerable and marginal Adivasi communities, which constitute a large fraction of those threatened with conservation-induced displacement in India. Given the broad institutional context of relocation from Protected Areas, there are two important reasons why it is difficult to envisage a delivery system that minimises resettlement risks and creates positive livelihood outcomes. First, the fluid, diverse, heavily natural resource-dependent nature of the pre-displacement livelihood practices of Adivasi households is very difficult to recreate in the 'mainstream' agrarian context. Second, their very marginalisation makes it difficult for them to organise effectively to ensure that implementation of rehabilitation programmes is efficient and adequate for livelihood restoration. For such communities, it is imperative that alternative, more benign, non-displacing methods be found for reconciling conservation goals with their local livelihood needs.

Thus, there are serious limits to the strategy of "preservation via dislocation' (as shown by Kuno), even though it is possible to obtain positive livelihood outcomes in some cases (as shown by Bhadra). In general, however, displacement as a conservation tool must be used sparingly, rather than as a policy of the first resort. In the rarest of rare cases of 'preservation via dislocation', well-designed delivery systems for proper resettlement and rehabilitation must be developed, and effective grievance redressal mechanisms must be created. Without such safeguards, displacement will continue to be a highly contentious conservation tool, which will sharpen 
the already serious human-wildlife conflicts to the detriment of conservation as well as human development goals. The success of Bhadra underscores this as emphatically as the failure of Kuno.

\section{Notes}

1. The term Adivasi refers to Scheduled Tribes, a category recognised as eligible for positive discrimination under Article 342 of the Constitution of India. It is the states in the Indian Union that put together a list of such groups within their borders.

2. However, the prevalence of poverty was observed to be much higher in all study villages when the narrow, purely monetary definition of income (Y2, denoting only cash income of a household) is used, compared to the broader measures (Y1 denoting total annual consumption flows, or the monetised value of consumption obtained from physical, financial, natural, social and human capital stocks held by a household, and Y3 which is analytically similar to Y2, but excludes money income created by external non-state actors like a local NGO).

3. Formally, the FGT Index is defined as

$F G T=\frac{1}{N} \sum_{i=1}^{p}\left(\frac{z-y_{i}}{z}\right)^{\alpha}$

4. Values of $\alpha>1$ allow the index to be increasingly sensitive to inequalities among the poor.

\section{REFERENCES}

Anon. 2002. Forgotten villages. Chikmagalur: Office of the District Collector.

Arun, A.K. 2005. Gaaon Mein Pasri Hui Hai Maut (Death spreads across the village). In: Outlook Saaptahik (In Hindi). Pp. 18-19. New Delhi.

Brockington, D. 2002. Fortress conservation: The preservation of the Mkomazi game reserve, Tanzania. Oxford: James Currey.

Brockington, D. and J. Igoe. 2006. Eviction for conservation: A global overview. Conservation and Society 4(3): 424-470.

Bunsha, D. 2005. Left high and dry. Frontline 22: 11.

Chatty, D. and M. Colchester (eds.). 2002. Conservation and mobile indigenous peoples: Displacement, forced settlement and sustainable development. Oxford, New York: Berghahn Books.

Cernea, M. 1997. The risks and reconstruction model for resettling displaced populations. World Development 25: 1569-1587.

Deaton, A. 2006. Measuring Poverty. In: Understanding Poverty (eds. Banerjee, A., R. Benabou and D. Mookerjee) Oxford University Press.

Forgotten Villages. 2002. A book on the Bhadra LA and R\&R experience. In: Companion publication for a film of the same name by Krupakar Senani. Chikmagalur: Published by the District Collector.

Geisler, C. 2003. A new kind of trouble: Evictions in Eden. (C) UNESCO 2003. UK and USA: Blackwell Publishing Ltd.

Grove, R.H. 1987. Early themes in African conservation: The Cape in the nineteenth century. In: Conservation in Africa: People, policies and practice (eds. Anderson, D. and R. Grove). Cambridge: Cambridge University Press.

Guruswamy, M. and R.J. Abraham. 2006. Redefining poverty: A new poverty line for a new India? Economic and Political Weekly 41(25): 2534-2541.

Jodha, N.S. 1986. Common property resources and the rural poor in dry regions of India. Economic and Political Weekly 21: 27.

Kabra, A. 2003. Displacement and rehabilitation of an Adivasi settlement: Case of Kuno wildlife sanctuary, Madhya Pradesh. Economic and Political Weekly 38(29): 3073-3087.

Kabra, A. 2007. Preservation via Dislocation. Seminar 577: 58-62.
Kabra, A. 2008. Displacement from wildlife protected areas and its impact on poverty and livelihood security: A study of Kuno wildlife sanctuary, Madhya Pradesh. PhD dissertation. Centre for Economic Studies and Planning, Jawaharlal Nehru University, Delhi, India.

Karanth, K.U. and K.K. Karanth. 2007. Free to move: Conservation and voluntary resettlements in the Western Ghats of Karnataka, India. In: Protected Areas and human displacement: A conservation perspective (eds. Redford and Fearn). New York: Wildlife Conservation Society.

Karanth, K.K., L.M. Curran, J.D. Reuning-Scherer. 2006. Village size and forest disturbance in Bhadra Wildlife Sanctuary, Western Ghats, India. Biological Conservation 128: 147-157.

Karanth, K.U. and R. Gopal. 2005. An ecology-based policy framework for human-tiger coexistence in India. In: People and wildlife: Conflict or coexistence? (eds. Woodroffe, R., S. Thirgood and A. Rabinowitz). Pp. 373-387. London: Cambridge University Press.

Karanth, K.K. 2005. Bhadra wildlife sanctuary: Addressing relocation and livelihood concerns. Economic and Political Weekly November 12.

Karanth, K.K. 2007. Making resettlement work: The case of India's Bhadra Wildlife Sanctuary. Biological Conservation 139: 315-324.

Karnataka Forest Department. 1999. Report on rehabilitation in Bhadra Tiger reserve. Bangalore: Karnataka Forest Department.

Kothari, A., N. Singh and S. Suri (eds.). 1996. People and Protected Areas: Towards participatory conservation in India. Delhi: Sage Publications.

Kothari, A., P. Pande, S. Singh and D. Variava. 1989. Management of National Parks and Sanctuaries in India: A status report. New Delhi: Indian Institute of Public Administration.

McCracken, J. 1987. Conservation priorities and local communities. In: Conservation in Africa: People, policies and practice (eds. Anderson, D. and R. Grove). Pp. 63-78. Cambridge: Cambridge University Press.

Participatory Research in Asia (PRIA). 1993. Doon declaration on people and parks resolution of the national workshop on declining access to and control over natural resources in national parks and sanctuaries. Forest Research Institute, Dehradun. 28-30 October 1993 (Society for Participatory Research in Asia).

Rangarajan and V. Saberwal. (eds.). 2003. Battles over nature: Science and the politics of conservation. New Delhi: Permanent Black.

Rangarajan, M. 2001. India's wildlife history: An introduction. Delhi: Permanent Black, in association with the Ranthambore Foundation.

Rangarajan, M. and G. Shahabuddin. 2006. Displacement and relocation from Protected Areas: Towards a biological and historical synthesis. Conservation and Society 4(3): 359-378.

Robbins, P. 2000. The Rotten institution: Corruption in natural resource management. Political Geography 19: 423-443.

Rossi, G. 2000. L'Ingérence écologique. Environnement et développement rural du Nord au Sud. Paris: CNRS.

Saberwal, V. and M. Rangarajan (eds.). 2003. Battles over nature: Science and the politics of conservation. Delhi: Permanent Black.

Saxena, N.C. 2007. Rehabilitating degraded lands. In: Environmental issues in India: A reader (ed. Rangarajan, M). New Delhi: Pearson-Longman.

Schmidt-Soltau, K. 2005. Is forced displacement acceptable in conservation projects? Id 21 insights 56.

Shah, A. 2005. Poverty and natural resources: Understanding the dynamics of dryland regions in western India. New Delhi: CPRC and IIPA Working Paper 25.

Sharma, A and A. Kabra. 2007. Displacement as a conservation tool: Lessons from Kuno wildlife sanctuary, Madhya Pradesh. In: Making conservation work (eds. Rangarajan, M. and G. Shahabuddin). New Delhi: Permanent Black.

Sinha, A.M. 1996. Madhya Pradesh District Gazetteers: Morena. Bhopal: Gazetteers Unit, Directorate of Rajbhasha Evam Sanskriti, Department of Culture, Government of Madhya Pradesh.

Sreekantaiah, G.N., S. Subramanya. 1992. Bhadra Wildlife sanctuary acquisition. Rehabilitation and resettlement project report. Bangalore: 
Karnataka Forest Department.

Tiani, A.M. and C. Diaw. 2006. Does resettlement contribute to conservation? The case of Ikundu-Kundu, Korup National Park, Cameroon. Policy Matters, Issue 14. In: IUCN Commission on Environment, Economic and Social Policy (CEESP). Switzerland: International Union for the Conservation of Nature.
Vijay Shankar, P.S. 2005. Four decades of agricultural development in MP: An agro-ecological sub-region approach. Economic and Political Weekly 40(48): 5014-5028.

Wildlife Institute of India. 1995. Survey of potential sites for the reintroduction of Asiatic lions. Unpublished Report. Dehra Dun: Wildlife Institute of India. 